\title{
Towards a Training Strategy for Church Communications
}

\section{by Franz-Josef Eilers}

During the last ten years or so, almost every meeting, conference or workshop of Church-related bodies in Asia, Africa, Oceania and Latin America has stressed the importance of training for communications. Looking at the reality of things, however, there are very few fully trained people available, and this holds for both lay people as well as for priests and religious, at least in what concerns the internal communications structures of the Church. A start has been made in some areas such as the AMECEA ${ }^{1}$ countries in Eastern and Central Africa and in some regions of India, where the Tamil Nadu bishops have sent five priests to undergo full communications training. Apart from these instances, the impression gained is that there is a lack of strategy or planning and carrying out training for individuals and in organising training courses.

In the Pastoral Instruction 'Communio et Progressio' 1971, training is seen as a need for the recipients ${ }^{2}$ as well as for communicators. If the communications structure of the Church is to be consolidated, then training with specific roles in mind is vital. The same can, of course, be said of any training strategy not connected with the Church.

\section{Human personality}

'Communio et Progressio' makes it quite clear that the training for communications requires first of all certain human and christian qualifications as the basis of any communicative work. "Human qualities as well as professional competence should be developed. Since the media of social communications are for mankind, communicators should be consumed by the desire to serve their fellow men. The more communicators remember that beyond the lifeless instruments which pass on their words and images are countless living men and women, the more satisfaction will they derive from their work and the better will they help others. The more they get to know their audience the more they understand it and appreciate it, the more will they suit what they communicate to those who receive it. If they do this, they help to make the process of communication a communion of the spirit." 3

These are basic considerations showing the principles by which a professional training should be carried out. What steps, then, should be taken with regard to the communications development in a given area?

\section{Analysis of needs and possibilities}

In any strategy for communications there should be as clear a picture as possible of the local, national and regional needs for trained communicators. Acommercial radio system in one country might call for more workers than, for example, a staterun system in which the Church is allocated only a few minutes air-time. The possibilities and the needs for communication in development projects might call for specialists in both communications media and catechetics.

There might also be the need for teaching and research on communications at University or College level. Unless the needs and opportunities in any given area are known it is difficult to devide on plans for training. A general survey of the needs and possible development for a future five-year period would help in this planning. The experience and 
insights from other parts of Africa, Asia or Latin America in their communications work and training might also be taken into consideration. What steps would then be taken after this "market analysis" has been made?

\section{Training in three stages}

Basically the strategy in training for communication can be seen on three levels, and carried out in three stages, as outlined by the Recommendations on the Conference on "Communications in Development" held in Lusaka in December 19714.

\section{1st Stage: Careful selection of candidates.}

This selection should be based on abilities and potential. Short workshops of an introductory character often serve as pointers, and these could take place on the local level.

2nd stage: Initial training.

Initial training should definitely be given in the country or at least in the continent where the candidate is to spend most of his working life. Comparatively short courses, such as those offered by the All Africa Conference of Churches Training Centre (for Radio) in Nairobi, or the African Literature Centre (for Journalism) in Kitwe are examples of the training possibilities of this kind. Training at other than Church centres and in-service training might also be considered. The training should be chosen for its suitability to the trainee's aptitudes and the work he will be expected to do. Churches should whereever possible, avoid sending a person straight from school to further training, but should provide work-experience first.

The expenses for such initial training should preferably be borne by the local Churches or their respective organisations.

\section{3rd stage: Further training.}

Further training should be made available only if the candidate has had a period of work-experience and proves to be specially talented during this time. Further training should enable him to do his professional work better, and develop him personally for a more important and responsible position within the overall communications planning of his country or area.

Where suitable further institutional training is available in the candidate's own country or continent, these opportunities should receive preference. A suitable institution for further training either in Africa or overseas should be selected from all those available with strict attention to the needs and abilities of the individual and the post for which he is being trained.

At all times, communicators should make imaginative use of in-service training of all kinds, including the secular media, and exchange staff with other communications offices working in the same medium.

With regard to a candidate sponsored for further training, Churches should make written agreements regarding his future employment, and should ensure that they have faced their commitments involved in employing their candidate suitably when he returns. 


\section{Clearly defined aims for training.}

In communications work of a local Church or on other levels, there are different media, such as Press, Radio, TV, Film, audio-visual or communications in general, and within the different media there are also different offices, such as editorial work, production, and especially management. A good editor is not necessarily a good manager. For the smooth running of a communications undertaking a structure is essential. Therefore, training for management of Christian Communications projects is a particular priority in view of the number of Church programmes which have failed partly through lack of management skills. It is not fair to expect that a man trained as a communicator should also be a natural manager. The present investment in training communicators is often lost for the want of managerial ability.

In recent years some areas have sent personnel overseas to learn how to produce a radio or television programme. This is certainly necessary, but in a long range planning it seems to be just as important to have a few people go into communications research and academic studies. In view of future needs there should also be specialists who can see beyond daily production and give some time to research. Planning for communications would be incomplete if this need is not recognised and day-to-day production seen as the only work to be done.

Training of personnel obviously calls for training opportunities. In some places Church institutions try to provide this training. There is a wide field open especially for Christian Universities and academic institutions, and such centres should be strengthened and become a permanent part of the Church's training structure. There are, of course, also secular training schools offering specialised courses. Where these exist their facilities should be used in order to avoid unnecessary duplication of technical resources and staff.

\section{Footnotes}

1 AMECEA - Association of the Episcopal Conferences in East Africa (Kenya, Uganda, Tanzania, Malawi and Zambia).

2 'Communio et Progressio' Nos. 65-70.

3 'Communio et Progressio' Nos. 71 and 72.

${ }^{4}$ In 'African Accents', Lusaka 1971, p. 12 (A Report of a Conference on Communications in Development.)

\section{ZUSAMMENFASSUNG}

Die Notwendigkeit einer fachlichen Ausbildung im Kommunikationsbereich ist in den vergangenen Jahren bei fast allen Fachkonferenzen in Asien, Afrika, Ozeanien und Lateinamerika als erste Priorität genannt worden. Dabei kommen die Ergebnisse über einige wenige gute Ansätze etwa für die Länder des östlichen Afrika (AMECEA) oderdie Region Tamil Nadu derindischen Bischofskonferenz kaum hinaus. Es fehlt immer noch an der gezielten Planung und Durchführung für die Ausbildung Einzelner und ganzer Gruppen. Dabei betont die pastorale Instruktion COMMUNIO ET PROGRESSIO sowohl die Ausbildung für die Empfänger als auch für die Kommunikatoren.

Für COMMUNIO ET PROGRESSIO ist es ganz klar, daß die fachliche Ausbildung auch die „kulturellen und menschlichen Probleme” einbeziehen muß, denn die Kommunikatoren 
müssen „vom Bewußtsein getragen werden, den Menschen immer dienen zu wollen”, weil jenseits „der technischen Kanäle . . Menschen von Fleisch und Blut leben." (COMMUNIO ET PROGRESSIO No. 72). Dies sind Basisüberzeugungen, die jeder Ausbildung zugrunde liegen.

Für eine Kommunikationsstrategie aber muß man dann auch die tatsächlichen Bedürfnisse auf lokaler, nationaler und regionaler Ebene feststellen, um zu wissen, welche Fachleute für was auszubilden sind. Ein kommerzielles Rundfunksystem z.B. stellt auch an die Kirche andere Forderungen und gibt ihr andere Möglichkeiten als etwa ein staatlicher Rundfunk. Auch sollten Lehre und Forschung an den Universitäten nicht vergessen werden! Welche Schritte sind nun nach einer solchen „Marktanalyse” zu unternehmen?

Nach den Vorstellungen einer Konferenz über „Kommunikation und Entwicklung” in Lusaka 1971 sollte alle Ausbildung in drei Schritten erfolgen:

Im ersten Schritt sind mögliche Kandidaten durch kurze Arbeits- und Einführungskonferenzen herauszufinden und dann zunächst auf lokaler Ebene in Kommunikationsarbeit einzuführen.

Der zweite Schritt wird dann möglichst im Land selbst oder zumindest im gleichen Kontinent eine weitere Ausbildung vermitteln. Dies geschieht z.B. durch halbjährige oder mehrmonatige Kurzkurse, wie sie etwa von verschiedenen christlichen Ausbildungsstätten Afrikas angeboten werden. Niemand sollte dabei allerdings ohne jede praktische Erfahrung von einem Studium in das andere geschickt werden.

Schritt drei der Ausbildung, die Weiterbildung, wird dann vorgesehen, wenn der betreffende Kandidat seine Qualifikation durch erfolgreiche längere Arbeit bewiesen hat. Diese Weiterbildung sollte allerdings bestimmt werden von jener zukünftigen Aufgabe des Betreffenden, die er in seinem eigenen Land nach der Ausbildung übernehmen soll.

Wo gute Möglichkeiten für eine Inservice-Ausbildung bestehen, sollten diese genutzt werden. Um sich vor jeder Studieninvestition abzusichern, müßten die Kirchen für ihre Kandidaten eine schriftliche Abmachung vorsehen, in der sie sich verpflichten, nach ihrer Ausbildung wenigstens einige Jahre oder einen bestimmten Zeitraum im kirchlichen Dienst zu verbleiben. İnsgesamt sollte man sich darüber klar sein, welche Art einer Ausbildung man tatsächlich für die betreffenden Aufgaben einer bestimmten Kirche notwendig hat und welche Prioritäten sich daraus ergeben. Ein guter Redakteur ist z.B. nicht unbedingt ein guter Manager. Auch muß das Niveau der Ausbildung berücksichtigt werden: Die Ausbildung von Praktikern allein reicht nicht wenn man auf längere Sicht plant und Einsicht in die kommunikativen Prozesse und Entwicklungen auch in der Zukunft haben will. Hier ist wohl eine entsprechende akademische Weiterbildung zu fordern.

Zwar hat die Kirche bereits eigene Ausbildungszentren, aber andererseits sollten auch bestehende weltliche Bildungsmöglichkeiten von kirchlichen Kandidaten so weit wie möglich genutzt werden. 


\section{RÉSUMÉ}

La formation professionelle dans le domaine de la communication s'avère nécessaire. Presque toutes les conférences spécialisées des dernières années, en Asie, en Afrique, en Océanie et en Amérique Latine l'ont dit. Cependant, la planification et l'exécution dans un but précis manquent en grande partie, chez les individus comme dans les groupes bien que l'instruction pastorale "Communio et Progressio" les mentionnent avec insistance. Une stratégie de la communication doit surtout reconnaître les besoins à une échelle locale, nationale et régionale. Quels spécialistes sont utilisés où de la part de l'Eglise? C'est la question fondamentale à laquelle la formation doit alors se conformer. A la question au sujet d'une bonne formation a déjà répondu une conférence sur la «Communication et le développement» en 1971 à Lusaka. Elle exigea trois étapes dans la formation: des conférences de travail et d'initiation pour les candidats possibles; des cours de six ou plusieurs mois dans le pays ou le continent; et une formation continue approfondie dans le cercle culturel propre ou le cas échéant outre-mer, cependant toujours découpé en fonction de la tâche future d'une nature bien spéciale. En cela, les priorités respectives doivent être observées. On doit utiliser les centres de formation appartenant à l'Eglise, cependant les possibilités de formation laiques des candidats religieux doivent être également épuisées.

\section{RESUMEN}

La formación profesional en el sector de la comunicación social aparece como necesaria. Lo confirmen casi todas las conferencias monográficas celebradas durante los últimos años en Asia, Africa, Oceanía y Latinoamérica. Pero falta todavía una planificación y realización concreta, particular ó en grupo, a pesar de que la Instrucción Pastoral "Communio et Progressio» insistió expresamente en ello. Una estrategia de la comunicación social tiene que apuntar sobre todo a las necesidades a nivel local, nacional y regional. El interrogante fundamental es: ¿Qué especialistas necesita la Iglesia y dónde? A ello debe orientarse después la formación. Al interrogante de una buena formación respondió ya una conferencia sobre "Comunicación y desarrollo" celebrada en Lusaka en 1971. Exigió tres etapas didácticas: Conferencias de iniciación para posible candidatos; cursos breves, un semestre ó solo algunos meses, en el país ó el continente; formación superior en círculos culturales propios ó en ultramar, orientados siempre a la futura actividad especifica. En este contexto deben respetarse las respectivas prioridades. Deben aprovecharse propios centros eclesiales de formación, pero los candidatos de la Iglesia deben agotar también las posibilidades de formación laica. 